FIU Law Review

Spring 2015

\title{
Sifting Through the Theories: Uncovering the Truth in Foreign Aviation Disasters and Evaluating the Case
}

Steven C. Marks

Podhurst Orseck, P.A

Follow this and additional works at: https://ecollections.law.fiu.edu/lawreview

Part of the Other Law Commons

Online ISSN: 2643-7759

Recommended Citation

Steven C. Marks, Sifting Through the Theories: Uncovering the Truth in Foreign Aviation Disasters and Evaluating the Case, 10 FIU L. Rev. 571 (2015).

DOI: https://dx.doi.org/10.25148/lawrev.10.2.14

This Article is brought to you for free and open access by eCollections. It has been accepted for inclusion in FIU Law Review by an authorized editor of eCollections. For more information, please contact lisdavis@fiu.edu. 


\title{
Sifting Through the Theories: Uncovering the Truth in Foreign Aviation Disasters and Evaluating the Case
}

\author{
Steven C. Marks ${ }^{*}$
}

\section{INTRODUCTION}

A plaintiff's path to resolution in foreign aviation disasters comes with unique challenges and pitfalls that even the most experienced litigator may not anticipate. Successfully litigating foreign aviation cases requires as much determination as it does specialized know-how and diligent preparation. Because of the extraordinary expense involved in financing an aviation case, it is imperative to analyze the cases from a bird's-eye view to anticipate the challenges and avoid the all-too-common pitfalls ahead. This paper provides insight into how an aviation practitioner prepares and evaluates a foreign aviation case, and also provides a pre-trial road map to resolution.

\section{FOREIGN LAW AND LOCAL BAR RULES}

The first step in litigating foreign aviation cases is to adequately research any relevant foreign country's aviation law. Such foreign countries would include the place of accident, the decedent/injured and his or her family's place of residence, and the manufacturers and maintenance providers' location(s). The inquiry should include local bar rules and any other requirements applicable to attorneys in the forum country.

For instance, it is particularly important in foreign aviation cases to determine who has the requisite authority to retain an attorney on behalf of a decedent's estate, beneficiaries, or injured minor(s). In Florida, for example, the personal representative of the decedent's estate has the sole authority to retain an attorney to bring any and all claims on behalf of the decedent's estate. This person is usually the spouse, parent, or adult child of the decedent. In many other countries, however, the scope of retention authority is far broader. In some foreign jurisdictions, any person who received financial support from the decedent is authorized, and within his or her legal right, to retain an attorney and institute a suit on behalf of the decedent. Further, in certain countries, each Beneficiary has her own claims

* A partner at the law firm of Podhurst Orseck, P.A. in Miami, Florida. Special thanks to Joshua E. Rasco of Podhurst Orseck for his assistance in writing this Article; the FIU Law Review staff for its editorial contributions; and Dean R. Alexander Acosta for hosting the Aviation and Space Law Symposium. 
for an individual cause of action and must individually bring those claims. It is imperative that all of the correct and proper parties sign the attorney's retainer agreement, or the agreement may later be determined invalid.

\section{FOREIGN ACCIDENT INVESTIGATIONS}

Another crucial aspect of any foreign aviation case is the accident investigation. Aviation practitioners on the plaintiffs' side begin almost every case at an informational disadvantage. Unlike most other fields of civil litigation, interested parties such as aircraft and component manufacturers are called upon to assist government investigators in determining the cause of the crash. The government agency leading the investigation often relies upon and incorporates the findings and conclusions of the participating interested parties into its final report. Aviation practitioners must be vigilant when analyzing these final reports to ensure that a full and thorough investigation was completed. This is especially true with most commercial aviation disasters, which are widely publicized, and the theories and findings of the investigation teams can "poison the well" of public perception, or worse yet, that of the aviation practitioner.

The best way to overcome these disadvantages is to immediately begin your own, independent investigation into the cause of the crash. Generally, the victims and their representatives are not allowed to participate in the official accident investigation, or allowed access to the wreckage site or crucial maintenance records. As such, it is important to remain mindful of the parties involved in the official accident investigation, as well as their possible motives, so as to not prematurely discount any single theory and remain vigilant of spurious theories.

\section{A. Who May Participate in the Official Accident Investigation?}

The accident investigation of any foreign aviation disaster is generally governed by the International Standards and Recommended Practices (SARPs) published by the International Civil Aviation Organization (ICAO). ${ }^{1}$ ICAO's accident investigation protocol $^{2}$ (or "Annex 13") requires

1 ICAO is a specialized agency of the United Nations that was established upon the signing of the Convention on International Civil Aviation, Convention on International Civil Aviation, Dec. 7, 1944-Feb. 28, 1945, 61 Stat. 1180, 15 U.N.T.S 295 [hereinafter Chicago Convention], and currently has 191 signatory Member States. ICAO was created to aid the global aviation community in establishing uniform industry standards and practices. About ICAO, INT'L CIVIL AVIATION ORG., http://www.icao.int/about-icao/Pages/default.aspx (last visited Dec. 4, 2014).

2 Annex 13 to the Chicago Convention sets forth the SARPs for Aircraft Accident and Incident Investigation. Aircraft Accident and Incident Investigation, Chicago Convention on International Civil Aviation, Annex 13 (10th ed. 2010). 
that the state of occurrence ${ }^{3}$ initiate an accident investigation and secure the wreckage site. ${ }^{4}$ The state heading the investigation may delegate the whole, or any part, of the investigation to other entities, such as manufacturers, airline and maintenance companies, and many other potentially-interested parties. ${ }^{5}$ An aviation practitioner should be wary that a participating interested party's perception may be skewed by their belief in their product. In some cases, interested parties may go so far as to intentionally attempt to destroy or alter the evidence through disassembly or destructive testing. ${ }^{6}$

\section{B. Rely on Your Experts to Determine the Cause of the Crash}

Long before any theory of the official investigation becomes part of the investigative authority's final report, your team of experts should have already developed their own theories into the cause of crash. This task is, of course, easier said than done. Experts in the field of aviation are interdependent by nature. For example, an aerodynamics expert will undoubtedly rely on the conclusions of the meteorology expert. Similarly, an accident reconstruction expert will likely rely on the aerodynamics expert, meteorology expert, and human factors expert, just to name a few. This process requires considerable expense, diligence, and most importantly, the ability to review the final report of the investigating authority_and the evidence-impartially. The 1997 SilkAir disaster is illustrative of this point.

\section{i. 1997 SilkAir Disaster}

On December 19, 1997, SilkAir flight MI185 from Jakarta, Indonesia, to Singapore, crashed into the Musi River in southern Sumatra, killing all 104 occupants aboard the plane. ${ }^{7}$ Because Indonesia was the state of occurrence, Indonesia's National Transportation Safety Committee (NTSC) led the investigation. ${ }^{8}$ Other participants in the investigation included the U.S. National Transportation Safety Board (NTSB), the Australian Transport Safety Bureau (ATSB), ${ }^{9}$ and expert teams from manufacturers

3 Under Annex 13, the State of Occurrence is simply the country or territory in which the crash occurred. Chicago Convention, supra note 1, at 1-3.

4 Chicago Convention, supra note 1, at 93.2 .

5 Id. at qฯ 5.1, 5.23-5.26.

6 See, e.g., Silk Air Flight MI 185, NAT'L TRANSP. SAFETy CoMm. REV. ReP. § 1.16.1 (2001) [hereinafter N.T.S.C].

7 N.T.S.C., supra note 6 , at $\S 1.1$.

8 Under Annex 13, Indonesia was responsible for leading the investigation and securing the crash site. Chicago Convention on International Civil Aviation, supra note 3, at 5-1, 1 5.1; see N.T.S.C., supra note 6 , at $\S 1.1$.

9 At the time of the investigation, the ATSB was known as the Australian Bureau of Air Safety Investigation or BASI. This paper refers to the organization by its current name, the ATSB. 
such as the Boeing Company and General Electric. ${ }^{10}$

Captain Tsu Way Ming was the pilot-in-command of the Boeing 737$36 \mathrm{~N} .{ }^{11}$ Only a few minutes after the plane reached its planned cruising altitude of 35,000 feet, the cockpit voice recorder (CVR) ceased recording. ${ }^{12}$ The air traffic controller instructed the aircraft that it was abeam Palembang, Indonesia, which the crew acknowledged in its final communication. ${ }^{13}$ According to the final report, the flight data recorder (FDR) stopped working just a few minutes after the CVR stopped recording. ${ }^{14}$ Seconds later, the aircraft began a precipitous nose-dive into the Musi River, where it ultimately crashed. ${ }^{15}$

\section{a. The Controversy}

This SilkAir disaster is one of the most controversial commercial airline crashes in recent history. The controversy centered on the highlydisputed cause of crash. Based on the findings of the accident investigation, mechanical failure was purportedly ruled out. Pilot suicide became the prevailing theory amongst the official investigation participants and the global aviation community. Despite this, the state heading the investigation-Indonesia-concluded that the cause of the crash could not be determined.

The NTSB, with the assistance of the various component manufacturers and Boeing, conducted tests on the aircraft's components but determined that no mechanical malfunction had occurred. ${ }^{16}$ The NTSB ultimately concluded that the crash was caused by human intervention; specifically, that Captain Tsu Way Ming intentionally caused the airplane to crash. ${ }^{17}$ A number of findings throughout the investigation led the NTSB to conclude that only human factors could explain the tragedy. ${ }^{18}$ Some of the most compelling findings were that: the Captain took out a life insurance policy the week before the crash; he had recently exhibited uncharacteristic disciplinary problems at work, leading to demotion; and he was

10 Macarthur Job, Final flight: SilkAir, FLIGHT SAFETY AuSTRALIA, Jan.-Feb. 2008, at 20, available at http://www.casa.gov.au/fsa/2008/feb/18-28.pdf; Valerie Chew, Crash of SilkAir Flight MI 185, SINGAPORE INFOPEDIA, http://eresources.nlb.gov.sg/infopedia/articles/SIP_1576_2009-09-30.html (last visited Dec. 8, 2014).

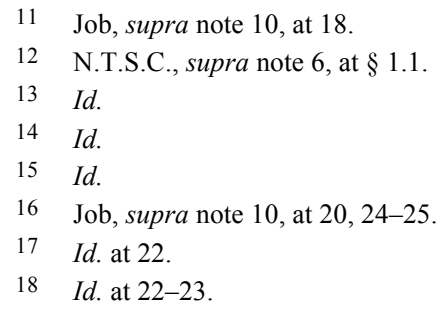


experiencing financial troubles. ${ }^{19}$ In addition to the evidence indicating the Captain's possible motive, there was no indication that the crew members attempted to recover from the plane's precipitous nosedive. Further adding to the theory of pilot suicide-murder is that the settings of the stabilizer trim and auto-throttle, both of which were in normal cruising settings before the plane began its rapid descent, were moved to compromising positions at some point between the time immediately prior to the descent and the time of impact. ${ }^{20}$ The trim was set to its full "nose-down" setting, and the autothrottle, which would have reduced engine power when the plane began to dive, had been disengaged. ${ }^{21}$ These findings led to a criminal investigation by the Singapore Police into a possible suicide-murder. ${ }^{22}$ The police investigation concluded that both pilots lacked a criminal motive. ${ }^{23}$

The second theory-a defective rudder system - was not the popular view. The theory was that a defective servo-valve inside the power control unit (PCU), which controls the aircraft's rudder system, caused the crash. ${ }^{24}$ This defect would not have been an isolated incident, as defective servo valves had been detected in prior crashes involving Boeing 737 aircrafts. $^{25}$ This theory was quickly discounted by the investigators - and the global aviation community - as highly improbable. ${ }^{26}$

On December 14, 2000, the NTSC's three-year investigation concluded and it published its final report, sending shockwaves throughout the international aviation community, including the investigation participants. ${ }^{27}$ The NTSC's final report concluded that the "technical investigation has yielded no evidence to explain the cause of the accident." 28 The NTSC's findings and conclusions led to an unprecedented critique of the final report by the NTSB. ${ }^{29}$ Despite being unable to convince the NTSC of its pilot suicide theory, the NTSB's theory became the prevalent theory throughout the international aviation community.

\section{b. The Winning Theory}

Following the NTSC's final report, numerous lawsuits were initiated

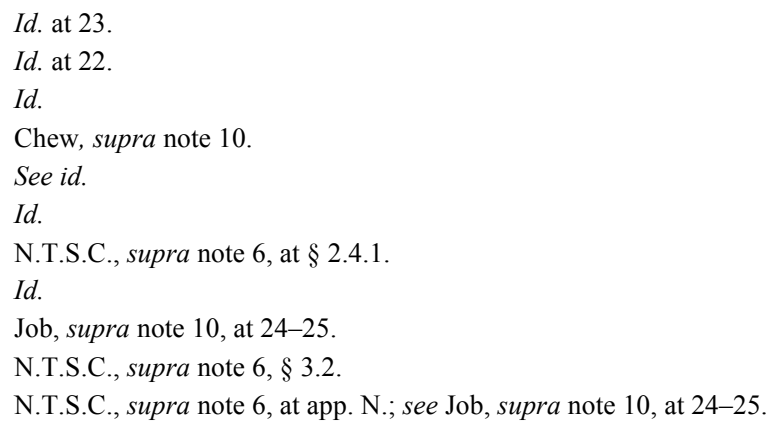


in Singapore and the United States. While many were unsuccessful, at least one resulted in a substantial jury verdict against Parker Hannifin Corp., the manufacturer of the defective servo valve. ${ }^{30}$

In spite of the prevalent belief that pilot suicide caused the crash, a thorough pre-litigation investigation uncovered evidence supporting the defective servo valve theory. The discovery that led to the evidence of a malfunction was contained in the FDR all along. The data from the FDR was initially believed to be unhelpful because the investigators concluded that the FDR stopped recording before the aircraft began its descent. This conclusion was wrong. In fact, the FDR continued recording until just before the aircraft crashed into the Musi River, and its contents indicated a malfunction in the aircraft's rudder system.

Upon presentation of this evidence, a jury in Los Angeles, California, returned a unanimous verdict finding the defective rudder system to be the sole cause of the crash. Following the verdict, Boeing dropped a lawsuit against SilkAir and the remaining families settled their lawsuits with Parker Hannifin.

\section{SETTLing Claims With ForeIgn DEFENDANTS}

Once your experts have determined the most likely cause, or causes, of the crash, you must next identify the appropriate defendants and make good faith efforts to settle with any foreign defendants in the case. This ensures that domestic defendants will not be able to prolong, halt, or stall litigation by claiming that essential foreign defendants are absent from the litigation. ${ }^{31}$ This strategy will also aid in eliminating foreign law considerations and/or potential problems such as deposing witnesses domiciled outside of the United States. ${ }^{32}$

In order to settle with foreign defendants at an early stage in the litigation, it is essential that you: (1) obtain comprehensive damage information as soon as possible; and, (2) have reasonable expectations. If you do these two things, you will be able to begin settlement negotiations at an early point in the lawsuit with foreign defendants, thereby eliminating one of the obstacles to trying the case in the United States.

30 Chew, supra note 10; Bee v. Parker Hannifin Corp., et al., No. BC-202587 (Cal. Super. Ct., Los Angeles County July 6, 2004).

31 See In re Air Crash Over the Mid-Atlantic on Jun. 1, 2009, 792 F.Supp. 2d 1090 (N.D. Cal. 2011) (dismissing a case for FNC when plaintiffs chose to omit defendants in foreign jurisdictions).

32 See U.S. Dep'T of State Foreign AfFairs Manual, 7 FAM 920 (2013), available at www.state.gov/documents/organization/86740.pdf. 


\section{FORUM NON CONVENIENS CONSIDERATIONS}

One of the most common roadblocks to litigating foreign aviation cases in the United States is a motion to dismiss for forum non conveniens (FNC). It provides defendants with the means to have a case dismissed, requiring the plaintiff to re-file in a forum that may be highly unfavorable to the plaintiff. A motion to dismiss based on FNC also presents U.S. courts with an opportunity to move the docket, and there is little doubt that some courts improperly and unfairly grant FNC motions for this reason. ${ }^{33}$

\section{A. Applicable Standard}

Determination of a defendant's motion to dismiss for FNC is at the court's discretion and will only be reversed where there has been a clear abuse of discretion. ${ }^{34}$ Importantly, defendants have the burden of proof "as to all elements of the forum non conveniens analysis." 35 Defendants can carry that burden by "provid[ing] enough information to enable the District Court to balance the parties' interests.",36

\section{B. Availability and Adequacy of the Forum}

The defendant's first step is to prove that the suggested alternative forum is able and willing to accept jurisdiction over the entire case, i.e., the subject matter of the case and all parties. ${ }^{37}$ In multi-plaintiff and multidefendant cases, the moving party must find a single "judicial roof" where all the multiple cases can be litigated. ${ }^{38}$ Thus, an FNC motion is not proper, and most likely will not be granted, if it will magnify the judicial workload by distributing an action between two or more courts. ${ }^{39}$

33 While a district court cannot rely solely on docket congestion when dismissing for forum non conveniens, it may consider congestion as one of several relevant factors. Fortaner v. Boeing Co., 504 F. App'x 573, 581 (9th Cir. 2013).

34 See Magnin v. Teledyne Cont'l Motors, 91 F.3d 1424, 1429 (11th Cir. 1996); Bhatnagar v. Surrendra Overseas Ltd., 52 F.3d 1220, 1225 (3d Cir. 1995); Rivendell Forest Prods., Ltd. v. Canadian Pac., Ltd., 2 F.3d 990, 992 (10th Cir. 1993); R. Maganlal \& Co. v. M.G. Chem. Co., 942 F.2d 164, 167 (2d Cir. 1991); Reid-Walen v. Hansen, 933 F.2d 1390, 1393-94 (8th Cir. 1991).

35 Lacey v. Cessna Aircraft Co., 862 F.2d 38, 43-44 (3d Cir. 1988).

36 Piper Aircraft Co. v. Reyno, 454 U.S. 235, 258-59, n.27 (1981); accord Baris v. Sulpicio Lines, Inc., 932 F.2d 1540, 1551 (5th Cir. 1991); Lacey, 862 F.2d at 44 (denial of motion affirmed; defendant provided insufficient information to support allegations); La Seguridad v. Transytur Line, 707 F.2d 1304, 1309 (11th Cir. 1983).

37 See La Seguridad, 707 F.2d at 1307.

38 Lacey, 862 F.2d at 183, 190 n.10.

39 See, e.g., Friends for All Children, Inc. v. Lockheed Aircraft Corp., 717 F.2d 602, 609 (D.C. Cir. 1983); accord In re Air Crash Off Long Island, N.Y., on Jul. 17, 1996, 65 F. Supp. 2d 207, 217-218 (S.D.N.Y. 1999) ("piecemeal litigation" and "prospect of several trials simultaneously taking place in different countries around the world weigh[] against dismissal"); Complaint of Maritima Aragua, S.A., 823 F.Supp. 143, 148 (S.D.N.Y. 1993) (rejecting forum non conveniens motion because of a related 
Not only must the defendant submit to jurisdiction in the alternative forum, but the forum court must also permit litigation of the subject matter of the dispute. ${ }^{40}$ Generally, the defendant will submit to jurisdiction in the other forum. The defendant's showing must be made by affidavit or other appropriate evidence. ${ }^{41}$ Courts may dismiss a case with orders to reinstate if jurisdiction is ultimately rejected by the court of the alternative forum. ${ }^{42} \mathrm{~A}$ court may, however, determine that dismissal is improper where "the remedy provided by the alternative forum is so clearly inadequate or unsatisfactory that it is no remedy at all., ${ }^{, 43}$

Another important consideration in determining the adequacy of the forum is the applicability of the jurisdictional provisions of the Montreal Convention. In West Caribbean Airways, S.A., the plaintiffs, who were residents of the Island of Martinique - a region of the French Republiccontended that the defendant travel agency's status as a contracting carrier conferred mandatory jurisdiction on the District Court pursuant to Article 33 of the Montreal Convention, thereby precluding dismissal of the action on FNC grounds. ${ }^{44}$ The defendants, seeking dismissal to a Martinique court, asserted that the Convention's drafting history reflected that the signatory States contemplated FNC remaining a valuable procedural tool for the dismissal of actions with weak ties to the United States. ${ }^{45}$ The District Court found in favor of the defendants noting that the text of the Convention permitted application of the FNC doctrine in Montreal Convention cases and that the FNC doctrine was applicable to the case pursuant to Article $33(4)^{46}$ of the Convention. ${ }^{47}$ The District Court ultimately dismissed the

lawsuit involving the same subject matter over which the alternative forum had no jurisdiction); In re Seatrain Lines, Inc., 32 B.R. 669, 672 (Bankr. S.D.N.Y. 1983) (declining to dismiss a counterclaim to Guatemala where other related proceedings would remain in the United States); Ruchti v. Boeing Co., 18 AVI. 17, 153-154 (E.D. Pa. 1983) (retaining European cases because of pendency of American cases).

40 Norex Petroleum Ltd. v. Access Indus., 416 F.3d 146, 157 (2d Cir. 2005) (earlier potentially adverse default judgment rendered Russian courts unavailable); Aguinda v. Texaco, Inc., 303 F.3d 470, 477 (2d Cir. 2002); Mercier v. Sheraton Int'1, Inc., 935 F.2d 419, 426 (1st Cir. 1991); Machline v. Nat'1 Helicopters, 1995 WL 251540 (S.D.N.Y. 1995) (Brazilian courts would not accept stipulation of liability).

41 In re Optimal U.S. Litig., 886 F. Supp. 2d 298, 303 (S.D.N.Y. 2012), reconsideration denied Oct. 10, 2012; El-Fadl v. Cent. Bank of Jordan, 75 F.3d 668, 677 (D.C. Cir. 1996); accord Lony v. E.I. duPont De Nemours \& Co., 886 F.2d 628, 633 (3d Cir. 1989); Marriott v. Sedco Forex Int'1 Res., Ltd., 827 F.Supp. 59, 69-71 (D. Mass. 1993).

42 King v. Cessna Aircraft Co., 562 F.3d 1374, 1384 (11th Cir. 2009).

43 Delgado v. Delta Air Lines, Inc., No. 12-23272-CIV, 2013 WL 9837970, at*3 (S.D. Fla. Aug. 20, 2013) (quoting Piper, 454 U.S. at 254).

44 In re W. Caribbean Airways, S.A., 619 F.Supp. 2d 1299, 1308 (S.D. Fla. 2007), aff'd sub nom; Pierre-Louis v. Newvac Corp., 584 F.3d 1052 (11th Cir. 2009).

45 Id.

46 Article 33(4) of the Montreal Convention provides, "Questions of procedure shall be governed by the law of the court seised of the case." Convention between the United States of America and other 
French plaintiffs, requiring them to re-file in a Martinique court. ${ }^{48}$ On appeal, the Eleventh Circuit affirmed the District Court's decision. ${ }^{49}$ Following dismissal from the U.S. court, the French plaintiffs re-filed in a Martinique court but argued that the court did not have jurisdiction under Article $33 .{ }^{50}$ A French appellate court initially agreed with the U.S. District Court's decision and determined that the Martinique court had jurisdiction, but the decision was overturned by the Cour de Cassation, ${ }^{51}$ which declared that under Articles 33(1) and 46 of the Convention, the French forum is no longer available once the plaintiff has chosen another forum. ${ }^{52}$

Notably, a more recent decision out of the Southern District of Florida-Delgado v. Delta Air Lines, Inc. — called into doubt the decision in West Caribbean Airways, effectively eliminating France as an alternative forum following an FNC dismissal. The Delgado court, unlike the West Caribbean Airways court, was compelled to consider the Cour de Cassation's interpretation of Articles 33(1) and 46, and thus arrived at a different conclusion in determining whether France is an available alternative forum. The Delgado court thus held, "in light of the recent decision from the Cour de Cassation, this Court expresses doubt as to the ability of the [p]laintiffs to reinstate their suit in France without 'undue inconvenience or prejudice' after a forum non conveniens dismissal." 53 Much like the French court's interpretation of the Montreal Convention's jurisdictional provisions significantly altered the availability of France as an available alternative forum, so may the decisions of the supreme courts of other signatories to the Convention. Practitioners should be fully aware of such precedent when preparing a response to an FNC motion to dismiss.

\section{Public- and Private-Interest Analysis}

If the defendant is able to show that an adequate alternative forum exists ${ }^{54}$ the defendant must then speak to the private- and public-interest

Governments on Aviation, at S. Treaty Doc. No. 106-45, May 28, 1999, T.I.A.S. No. 13038 (effective Nov. 4, 2003), available at http://www.state.gov/documents/organization/122935.pdf.

47 In re W. Caribbean Airways, S.A., 619 F.Supp. 2d at 1328.

48 Id.

49 Id.

50 Delgado, 2013 WL 9837970, at *2 (citing Cour de Cassation, le civ., Dec. 7, 2011, Bull. civ. I, No. Q10-30.919 (Fr.)).

51 The Cour de Cassation is one of France's four Supreme Courts, and it presides over cases concerning jurisdictional matters.

52 Delgado, 2013 WL 9837970, at *2 (citing Cour de Cass., le civ., Dec. 7, 2011, Bull. civ. I, No. Q10-30.919 (Fr.)).

53 Id. at $* 6$.

54 Some jurisdictions apply a different test. See Fireman's Fund Ins. v. Thyssen Min. Const. of Can., Ltd., 703 F.3d 488, 495 (10th Cir. 2012) (Courts apply a two-step test to determine whether a case may be dismissed under the forum non conveniens doctrine when the only alternative forum is in a 
factors described in Piper Aircraft Company v. Reyno. ${ }^{55}$ In evaluating all the private-/public-interest factors, each case is unique and dependent upon its own individual facts. ${ }^{56}$

A defendant does not carry his burden if the crucial factors are "in equipoise or near equipoise. $" 57$ Courts use different wording for the proposition, but essentially the defendant must show that the balance of factors strongly tips in favor of the proposed alternative forum. ${ }^{58}$ An FNC motion will be denied if it merely shifts an inconvenience or burden of the litigation from one forum to another. ${ }^{59}$

When balancing the private-interest factors ${ }^{60}$ the Eleventh Circuit has long mandated that District Courts must "require positive evidence of unusually extreme circumstances, and should be thoroughly convinced that material injustice is manifest before exercising any such discretion as may

foreign country. First, there must be "an adequate alternative forum in which the defendant is amenable to process." Second, the court must confirm that foreign law is applicable.).

55 Piper Aircraft Co. v. Reyno, 454 U.S. 235, n.6 (1981).

56 See Lacey v. Cessna Aircraft Co., 862 F.2d 38, 44 (3d Cir. 1988).

57 Gulf Oil Corp. v. Gilbert, 330 U.S. 501, 506-07 (1947).

58 Id. at 508; Windt v. Qwest Commc'ns Intern., Inc., 529 F.3d 183, 192 (3d Cir. 2008) (holding that defendants must show trial in the plaintiff's chosen forum would establish oppressiveness and vexation to a defendant out of all proportion to plaintiff's convenience); Kisano Trade \& Invest. Ltd. v. Lemster, 737 F.3d 869, 879 (3d Cir. 2013) (rejecting oppressiveness or vexation and holding "the movant must show that the balance of these [private and public interest] factors tips decidedly in favor of trial in the foreign forum"); Tazoe v. Airbus S.A.S., 631 F.3d 1321, 1334 (11th Cir. 2011) (showing a comparative inquiry that requires the district court to weigh the "relative" merits of each forum).

59 See Robinson v. Giarmarco \& Bill, 74 F.3d 253, 260 (11th Cir. 1996) (transfer would "merely shift inconvenience from the defendants to the plaintiff"); Reid-Walen, 933 F.2d at 1397 ("In whichever forum the case is tried, witnesses will have to travel or testify by deposition. If the suit is brought in the U.S., the parties will not have compulsory process over any Jamaican witnesses. By the same token, if the suit is brought in Jamaica, the parties will lack compulsory process over American witnesses."); Founding Church of Scientology v. Verlag, 536 F.2d 429, 436 (D.C. Cir. 1976) (risk of not securing live testimony equally applicable to both forums); Prevision Integral de Servs. Funerarios, S.A. de C.V. v. Kraft, 94 F. Supp. 2d 771, 779 (W.D. Tex. 2000) ("The expense of hiring an interpreter in this matter ... merely would be reversed-i.e., translating from English to Spanish - if this case were tried in Mexico"; there were documents in both languages; problems of compulsory process and impleader in both forums); McClellan v. Am. Eurocopter, Inc., 26 F. Supp. 2d 947, 951 (S.D. Tex. 1998) (because evidence and witnesses equally divided, "[a]t best, trial in Canada would merely shift any inconvenience from Defendant to Plaintiff. The doctrine of forum non conveniens should not be invoked for this purpose.”); Lugones v. Sandals Resorts, Inc., 875 F. Supp. 821, 824 (S.D. Fla. 1995) (witnesses in both places); Roynat, Inc. v. Richmond Transp. Corp., 772 F. Supp. 417, 422 (S.D. Ind. 1991) (witnesses in both places); Rudetsky v. O’Dowd, 660 F. Supp. 341, 347-48 (E.D.N.Y. 1987) (witnesses in both places).

60 The private-interest factors are: (1) relative ease of access to sources of proof; (2) availability of compulsory process for attendance of unwilling witnesses, and the cost of obtaining attendance of willing witnesses; (3) possibility of view of premises, if view would be appropriate to the action; (4) all other practical problems that make trial of a case easy, expeditious and inexpensive; and (5) enforceability of the judgment. Piper Aircraft Co., 454 U.S. at 241, n.6. 
exist to deny a United States citizen access to the courts of this country." It thus follows that a defendant's burden should be satisfied only in "unusually extreme" or "exceptional circumstances.",62

When balancing the public-interest factors, ${ }^{63}$ U.S. courts are required to consider both state and federal interests. ${ }^{64}$ As the Eleventh Circuit in SME Racks noted, "[t]here is a strong federal interest in making sure that plaintiffs who are United States citizens generally get to choose an American forum for bringing suit, rather than having their case relegated to a foreign jurisdiction. ${ }^{, 65}$

\section{The Place of Wrongdoing and the Place of Injury Are Significant}

Historically, when the place of wrongdoing and the place of injury are two different places, the choice-of-law analysis usually resolves in favor of the law of the place of wrongdoing. ${ }^{66}$ Both federal and state courts have consistently held that the place of wrongdoing has a greater interest in determining the issue of liability than the place of injury. ${ }^{67}$ The former jurisdiction has a greater interest in policing wrongful conduct that took place within its boundaries and providing redress of injuries caused by its citizens, especially when an accident involves criminal acts. ${ }^{68}$

When punishment through punitive damages is at issue, courts define the place of misconduct as the place of ultimate decision making - the place where a corporation made, or concealed, decisions regarding a product

61 SME Racks, Inc. v. Sistemas Mecanicos Para Electronica, S.A., 382 F.3d 1097, 1101-02 (11th Cir. 2004) (citing La Seguridad, 707 F.2d at 1308 n.7) (quoting Burt v. Isthmus Dev. Co., 218 F.2d 353, 357 (5th Cir. 1955)).

62 See id.; see also Gulf Oil Corp., 330 U.S. at 508-10.

63 The public-interest factors are: (1) the administrative difficulties flowing from court congestion; (2) the local interest in having localized controversies decided at home; (3) the interest in having the trial of a diversity case in a forum that is at home with the law that must govern the action; (4) the avoidance of unnecessary problems in conflict of laws, or in the application of foreign law; and,

(5) the unfairness of burdening citizens in an unrelated forum with jury duty. Piper Aircraft Co., 454 U.S. at 241, n.6.

64 SME Racks, Inc., 382 F.3d at 1104.

$65 I d$.

66 See Schultz v. Boy Scouts of Am., Inc., 480 N.E.2d 679, 683 (1985); Crowell v. Clay Hyder Trucking Lines, Inc., 700 So. 2d 120 (Fla. 2d DCA 1997).

67 See DiFederico v. Marriott Intern., Inc., 714 F.3d 796, 807 (4th Cir. 2013); GlobalNet Fin. Com. v. Frank Crystal \& Co., 449 F.3d 377, 384 (2d Cir. 2006); Richards v. United States, 369 U.S. 1, 10 (1962); Lehman v. Humphrey Cayman, Ltd., 713 F.2d 339, 345 n.6 (7th Cir. 1983); Hous. N. Hosp. Props. v. Telco Leasing, Inc., 688 F.2d 408, 409 (5th Cir. 1982); Vandeventer v. Four Corners Elec. Co., 663 F.2d 1016, 1019 (10th Cir. 1981); Henry v. Richardson-Merrill, Inc., 508 F.2d 28, 35-37 (3d Cir. 1975); Foster v. Day \& Zimmerman, Inc., 502 F.2d 867, 870 (8th Cir. 1974); L.D. Reeder Contractors of Ariz. v. Higgins Indus., 265 F.2d 768, 773-74 n.12 (9th Cir. 1959); Transamerica Leasing, Inc. v. La Republica de Venez., 21 F. Supp. 2d 47, 54 (D.D.C. 1998).

68 In re Air Crash Over Mid-Atlantic on June 1, 2009, 760 F. Supp. 2d 832 (N.D. Cal. 2010). 
alleged to be defective. On the other hand, decentralized contacts resulting from sales or the introduction of a product into the stream of commerce are not significant for punitive damages choice-of-law purposes.

\section{E. Deference to Plaintiff's Choice of Forum}

The defendant's difficult and heavy burden casts light on the importance of a plaintiff's right to choose a forum, which carries a "strong presumption" of correctness. ${ }^{69}$ Such deference is less significant when the plaintiff chooses a forum other than his or her residence ${ }^{70}$ but may be overcome by a strong showing of convenience. ${ }^{71}$ Because courts remain mindful that "any ... foreign person may prosecute in our courts," and "to deny him this privilege would manifest a want of comity,"72 a foreign plaintiff's choice of forum is still entitled to "significant" weight. ${ }^{73}$ Thus, even though a foreign plaintiff's choice of forum receives less deference than that of a U.S. citizen, defendants still have a significant burden to overcome. $^{74}$

\section{F. FNC Dismissal Is Not the End of the Road}

If your client's case is dismissed on FNC grounds in favor of a foreign court, you must prepare to handle the case in unfamiliar territory. First, it is imperative that you associate with qualified local counsel who is familiar with the relevant laws of the country in which you file the lawsuit. Second, you should keep in mind an often overlooked treaty that may result in the

69 Macedo v. Boeing Co., 693 F.2d 683, 688 (7th Cir. 1982). See Piper Aircraft Co., 454 U.S. at 255; Koster v. (Am.) Lumbermens Mutual Cas., 330 U.S. 518, 524 (1947); Gulf Oil Corp., 330 U.S. at 508; La Seguridad, 707 F.2d at 1307; McDonald's Corp. v. Bukele, 960 F. Supp. 1311, 1318 (N.D. Ill. 1997); Hond. Aircraft Registry, Ltd. v. Gov’t of Hond., 883 F. Supp. 685, 690 (S.D. Fla. 1995); Chierchia v. Treasure Cay Servs., 738 F. Supp. 1386, 1388 (S.D. Fla. 1990).

70 Piper Aircraft Co. v. Reyno, 454 U.S. 235, 255 (1981).

71 Lewis v. Lycoming, 917 F. Supp. 2d 366, 371 (E.D. Penn. 2013) (citing Lony, 866 F.2d at 634.

72 The Sapphire, 78 U.S. 164, 167 (1870).

73 Lehman v. Humphrey Cayman, Ltd., 713 F.2d 339, 341 (8th Cir. 1983); accord, Ravelo Monegro v. Rosa, 211 F.3d 509, 514 (9th Cir. 2000); Murray v. British Broad. Corp., 81 F.3d 287, 290 (2d Cir. 1996); R. Maganal \& Co. v. M.G. Chem. Co., 942 F.2d 164, 168 (2d Cir. 1991); Reid-Walen, 933 F.2d at 1396; Lony, 886 F.2d at 633 ("Piper's language about according less deference to a foreign plaintiff's forum choice is not an invitation to accord a foreign plaintiff's selection of an American forum no deference since dismissal for forum non conveniens is the exception rather than the rule"); Farmanfarmaian v. Gulf Oil Corp., 588 F.2d 880, 882 (2d Cir. 1978); Prevision Integral de Servs. Funerarios, 94 F. Supp. 2d at 778; Schwarzkopf Techs. Corp. v. Ingersoll Cutting Tool Co., 820 F. Supp. 150, 152 (D. Del. 1992); Chierchia, 738 F. Supp. at 1388 (foreigners' "choice of forum is entitled to slightly less deference than would otherwise be the case"); Chan Tse Ming v. Cordis Corp., 704 F.Supp. 217, 219 (S.D. Fla. 1989) (“Although Plaintiffs' foreign citizenship lessens the presumption in favor of their choice of forum, the burden of proof remains with the Defendant.").

74 SME Racks, Inc. v. Sistemas Mecanicos Para Electronica, S.A., 382 F.3d 1097, 1104 (11th Cir. 2004). 
application of United States law in a foreign forum, known as the Hague Convention on the Law Applicable to Products Liability.

The Convention went into effect in 1977 and establishes common provisions in international products liability cases regarding the application of law. The Convention applies to manufacturers for damages caused by a product in cases that are brought in one of the signatory countries. To date, fourteen European countries have signed and/or ratified the Convention, including Belgium, Croatia, Finland, France, Italy, Luxembourg, Montenegro, Netherlands, Norway, Portugal, Serbia, Slovenia, Spain, and the Former Yugoslav Republic of Macedonia. If your case is centered on products liability and you have to file the action in one of these signatory countries, an in-depth review of the Convention may prove beneficial, because under certain conditions, the law of the United States may apply to a foreign action.

\section{CONCLUSION}

The path to resolution in foreign aviation disasters is long and arduous, and comes at considerable expense. While this paper discussed many of the challenges unique to foreign aviation litigation, it is not exhaustive. One must still consider a number of other foreign-aviation-related issues that may arise, in addition to the vast hurdles and pitfalls associated with any other class of litigation. Aviation practitioners would be well-served to consider the potential roadblocks that stand in the way of resolution at the outset of representation, before millions of dollars are spent. 